\title{
COVID-19: Learning from Past Funding Initiatives and their Dismissal in Southeast Asia
}

\author{
Rosalia Sciortino \\ https://orcid.org/0000-0002-8510-3150
}

Institute for Population and Social Research (IPSR), Mahidol University, Thailand

\begin{abstract}
This article examines philanthropic funding of past efforts to control emerging infectious diseases in Southeast Asia and China. The recount, based on personal insights as a foundation professional and a review of both published and unpublished material, shows that American foundations and other likeminded donors identified the risks associated with zoonotic infections early on - including from the same coronavirus family that is causing the current COVID-19 pandemic - and were later followed by bilateral and multilateral donors investing greater resources. At the cusp of the 2000s, foundations played a leadership and catalyst role in advancing a transdisciplinary agenda to better understand and respond to new emerging threats and in building the necessary individual and institutional capacities for regional and local disease surveillance. For more than a decade, this concentration of resources and approaches was recognised as having contributed to better preparedness. Gradually, however, funding initiatives declined in value and intensity due to several internal and external factors. This article argues that COVID-19 arrives in the midst of an unfinished donor agenda and that it is important to reflect on why philanthropic foundations, and the development aid community more generally, found themselves unprepared for the pandemic in order to draw lessons for addressing today's crisis - and future outbreaks of emerging infectious diseases.
\end{abstract}

Keywords: philanthropy, development aid, emerging infectious diseases EIDs, COVID-19, pandemic, Southeast Asia, China

eTropic: electronic journal of studies in the tropics publishes new research from arts, humanities, social sciences and allied fields on the variety and interrelatedness of nature, culture, and society in the tropics. Published by James Cook University, a leading research institution on critical issues facing the world's Tropics. Free open access, Scopus Listed, Scimago Q2. Indexed in: Google Scholar, DOAJ, Crossref, Ulrich's, SHERPA/RoMEO, Pandora. ISSN 1448-2940. Creative Commons CC BY 4.0 free to download, save and reproduce. To cite, include: Author(s), Title, eTropic, volume, issue, year, pages and DOI: http://dx.doi.org/10.25120/etropic.20.1.2021.3784 
eTropic 20.1 (2021) Special Issue: Pandemic, Plague, Pestilence and the Tropics

\section{Philanthropy's Response to the Coronavirus Outbreak ${ }^{1}$}

$\mathrm{S}$ hortly after the outbreak of a new corona virus (SARS-CoV-2) causing the coronavirus disease (COVID-19) in Wuhan in December 2019, private donors became a crucial part of the collective response to the crisis. All over the country there was an outpouring of support from individuals, corporations, and foundations in an attempt to contain the epidemic within the Central China province of Hubei where Wuhan is located. According to the charity data platform, Yishan, as of April 2020 over 40,000 Chinese companies had contributed US\$ 5 billion to counter COVID-19 in the country. In the most affected province of Hubei, charitable donations surpassed the entire provincial fiscal budget allocated for disease control (He, 2020).

Wealthy Chinese philanthropists also quickly stepped in, most notable among them Jack Ma through his e-commerce giant Alibaba and namesake foundations. As a first step, he provided US\$144 million in medical supplies for Hubei province as the epicentre of the outbreak, before starting to fund vaccine development in other parts of China and abroad, and airlifting supplies all over the globe (Philanthropy News Digest, 2020). Top donors also included another two tech giants, search engine Baidu Inc and tech company Tencent Holdings, while firms in manufacturing, financial services and other sectors made multi-million donations for the provision of supplies, R\&D and health education (He, 2020).

In the first months of 2020, the virus spread within China and to Southeast and East Asia, and was declared a Public Health Emergency of International Concern. As the transmission continued further across the globe and became a pandemic in March 2020 , an increasing number of individual and corporate donations of all sizes poured in to provide relief, while more philanthropists and foundations became involved. In Europe, the Wellcome Trust's initial pledge of $£ 10$ million in February 2020 to accelerate research and support global efforts to tackle COVID-19 was followed by a multitude of wide-ranging commitments by foundations in Italy and other highly impacted countries to address the pandemic and protect the most vulnerable (European Foundation Center [EFC], 2020). In Southeast Asia, among other philanthropists, Indonesian Dato Sri Tahir of Mayapada Group and his Tahir Foundation donated US\$3.2 million to ease COVID-19's health and economic impacts in the country, and also made donations to Singapore and China (M2030, 2020); and Malaysia's property tycoon Tan Sri Lee Kim Yew helped deliver equipment and protective clothing to front-line workers (Lim, 2020). Further around the tropics in Africa, Trust Africa established the COVID-19 Africa Solidarity Fund to resource

\footnotetext{
${ }^{1}$ A shorter version of this article was previously published as an opinion piece in New Mandala (Sciortino, 2020) and republished in other online media. This paper has been significanly revised and updated.
} 
eTropic 20.1 (2021) Special Issue: Pandemic, Plague, Pestilence and the Tropics

Emergency Response Units deployed in several countries across the continent, starting from Senegal where the Trust is based (Sall, 2020).

Global media attention was especially captured by the pledges of American philanthropists. The first major commitment came in late January 2020 from the Bill and Melinda Gates Foundation (BMGF) and consisted of US\$ 5 million for the COVID19 response in China and US\$10 million worldwide, followed in early February with a greater pledge of up to US\$100 million "to improve detection, isolation and treatment efforts; protect at-risk populations in Africa and South Asia; and accelerate the development of vaccines, drugs and diagnostics", with even larger commitments ensuing in successive months (Bill \& Melinda Gates Foundation [BMGF], 2020). Among other high profile donors, Twitter co-founder Jack Dorsey committed US\$ 1 billion in shares of his current company Square to the Smart Small charitable fund for global COVID-19 relief; Amazon's Jeff Bezos donated US\$100 million for food banks; Facebook's Mark Zuckerberg pledged US\$ 30 million to the Gates Foundation and Wellcome Trust's joint research project, the COVID-19 Therapeutics Accelerator; and George Soros donated $€ 2$ million for the emergency in the Italian city of Milan and in Hungary, later followed by a US\$ 130 million commitment of his Open Society Foundation to ameliorate the impacts of the epidemic in the United States and globally (Gaspard, 2020; Neate, 2020).

Amidst the widespread praise for the 'generosity' of the planet's richest individuals and their foundations, some commentators voiced critiques (Intelligencer, 2020; Schleifer, 2020). It has been noted that this philanthropic wealth is based on the exploitation of loopholes in the same economic system that is creating unprecedented inequities (as highlighted by the pandemic); the amounts, no matter how staggering, are tiny when compared to the givers' fortunes; less wealthy individuals donate greater proportions of their incomes; donations are a fraction of public funding and official development aid (ODA); commitments do not necessarily result in actual donations or may shift funds away from other programmes; and taxes would be a more effective and fair method than reliance on gratuities out of accumulated wealth to fund social safety nets and public health (Hamilton, 2020; Hobson, 2020; Schleifer, 2020; Theodore, 2020).

These warranted critiques have, however, been submerged under a deluge of social media conspiracy theories which blame the same global elites of exploiting COVID-19 to fill their wallets and impose malevolent agendas. Bill Gates, in particular, has become a main target of suspicion for having stated in 2015 that a 'highly infectious virus' would do more damage to humanity than war - his supposedly prescient knowledge being taken by some as 'proof' that he had manufactured COVID-19 (Wakefield, 2020). Such fake news may be believed only by ignoring - as many 
eTropic 20.1 (2021) Special Issue: Pandemic, Plague, Pestilence and the Tropics

unfortunately do - the substantial body of knowledge and experience accumulated through philanthropic practice over time regarding the likelihood of emerging infectious disease outbreaks and the severity of future pandemics.

In fact, philanthropy, generally defined as the use of private capital for the public good and social change (Jung \& Harrow, 2015), has long played a role in supporting public health endeavours. Wealthy individuals and the philanthropic foundations they establish to grant funds to specific causes and strategic organisations have a distinguished history in the global fight against malaria, tuberculosis, HIVIAIDS; and, in more recent times, in the prevention and control of the growing number of newly emerging infectious diseases (EIDs). As philanthropists and development practitioners formulate strategic funding responses for the immediate COVID-19 pandemic crisis and beyond, it is important to look back to these seemingly forgotten initiatives to better understand why foundations, and more generally the global development community, found themselves unprepared for COVID-19 in spite of their accumulated experience; and, from this, draw lessons for addressing today's pandemic (and future ones).

This article contributes to this aim by presenting the extensive philanthropic work on newly EIDs that has occurred in Southeast Asia - with connections to China - over the past two decades from a participant's perspective. This time range and the choice of the region is not only related to my own career as a foundation and aid professional, ${ }^{2}$ but has a relevance of its own. Subsequent to the AIDS pandemic in the $1980 \mathrm{~s}^{3}$ there has in fact been an increase of other never-previously recognised pathogens with a prevalence in this part of Asia, among which are also viruses from the same Betacoronavirus family as COVID-19 (Fauci et al., 2005; Chao et al., 2020). Alongside personal insights and experience, the analysis draws on a review of both published and unpublished material to present an understanding of the donor landscape.

The analytical review demonstrates that early on, at the cusp of the 2000s, American foundations and other like-minded funders identified the risks associated with new waves of infectious diseases in the region and beyond (and here it is worth stressing in order to avoid further conspiracy theories that BMGF was not part of this pioneering group), with bilateral and multi-lateral donors investing much larger resources at a later

\footnotetext{
2 Among other roles, the author served as a gender and reproductive health program officer in the Ford Foundation's Jakarta and Manila offices, as regional director of the Rockefeller Foundation's Southeast Asia Office in Bangkok, as a senior health adviser to AusAid, and as regional director for Southeast and East Asia at the International Development Research Centre (IDRC) in Singapore and is an adviser and consultant to various bilateral and multilateral donors in the region.

3 The rich philanthropic experiences with HIVIAIDS in Southeast Asia are not discussed here, but a separate indepth analysis is surely worthy, as much could be learned for the current COVID-19 pandemic. Besides UN bodies, WHO and UNAIDS, foundations again played a pioneer role in supporting HIV prevention and the rights of People with HIV and other marginalised groups from the very start of the epidemic when countries resisted recognising the pandemic. Among the many foundations, the Ford Foundation deserves mention for its leadership in the early 1990 s.
} 
eTropic 20.1 (2021) Special Issue: Pandemic, Plague, Pestilence and the Tropics

stage. However, this funding from philanthropic foundations and aid organisations as well as the allocations of partner governments, decreased towards the end of the last decade - shifting to other causes and modalities. The factors contributing to this funding shift as well as the programmes' strengths and shortcomings are revealing for the current pandemic. Furthermore, this closer scrutiny of the philanthropic and aid landscape can be instrumental in moving public discussion from a blind fascination with multi-million dollar figures and generalised comments on the good and evil of philanthropy per se, to a deeper assessment of the effectiveness and strategic value of funding approaches so as to improve the response to COVID-19 and future epidemic outbreaks.

\section{Funding Infectious Disease Surveillance in the 2000s}

As early as two decades ago, in 1999, the Rockefeller Foundation played a pioneering role in funding surveillance of emerging infectious diseases with pandemic potential in Southeast Asia and China (and later in Eastern and Southern Africa). ${ }^{4}$ With its support regional infectious disease surveillance networks were started or strengthened "to control cross-border outbreaks at their sources" (Bond et al., 2017, Abstract). At the time, global alarm was focused either on HIVIAIDS or on the localised diffusion of more familiar infectious diseases in Southeast Asia. These included diarrheal diseases like cholera, as well as malaria, dengue, pneumonia, typhoid, and tuberculosis (Coker at al., 2011; Bond et al., 2017). Yet, experts and practitioners on the ground in Southeast Asia had become concerned about the likelihood of this part of the region becoming a hotspot of new zoonotic outbreaks with significant transnational impacts. The rapid market integration between countries in the region and with China, the encroachment of humans on natural ecosystems, the large-scale wildlife trade, and the commercialisation of livestock were all important contributing factors.

Responding to these concerns, in 2001 the newly established Asia office of the Rockefeller Foundation in Bangkok launched the Cross-Border Health $(\mathrm{CBH})$ component of its 'Learning Across Boundaries in the Greater Mekong Subregion' (LAB) programme, integrating pre-existing infectious disease surveillance work with grant-making on regional socio-economic dynamics and their transnational ramifications. While CBH granted an average of US\$2 million annually specifically for cross-border health, larger resources allocated to other components of the LAB during the years 2001-2007 funded interventions to address many of the socio-economic root

\footnotetext{
${ }^{4}$ The initiative was spearheaded by Sarah McFarlane and later, for Southeast Asia, by Katherine Bond. A key convener role was played by Suwit Wibulpolprasert from the Ministry of Public Health, Thailand (see Bond et al., 2017). The author served at the time as regional director for Asia and was responsible for establishing the office in 2000 and conceptualising and overseeing the regional program, including work on cross-border health and the grant-making on regional surveillance networks when transferred from the head office to the regional offices.
} 
eTropic 20.1 (2021) Special Issue: Pandemic, Plague, Pestilence and the Tropics

causes of disease transmission which resulted from increased regional integration and mobility, lop-sided development, and mounting demands on shared natural resources in China and mainland Southeast Asia:

\begin{abstract}
LAB proposed a broader vision of development as a systemic sociocultural and political transformation process, and invested in building the necessary capacities and institutional mechanisms to realize it. Grant-making supported the fostering of multidisciplinary knowledge and skills, the creation of multi-stakeholder venues and networks-inclusive of activists and public intellectuals so often ignored in regional policy debates-and the formation of regional governance systems and social movements to advocate for policy change and bring to public attention neglected, yet pressing, social development issues (Sciortino, 2016, p. 153)
\end{abstract}

In particular, $\mathrm{CBH}$ resourced the production of contextual knowledge and the building of intervention capacity to identify and stem transnational flows of infectious diseases. It also funded advocacy for public health policies considering gender and other societal structures and addressing the disproportionate impacts on the most vulnerable, particularly migrants and ethnic minorities in mountainous border areas. Learning from the HIV epidemic, civil society groups were considered key stakeholders in building community resilience and community-based surveillance, and it was stressed that mitigating fear and discrimination toward persons infected with, and affected by, infectious disease was crucial in controlling transmission (Sciortino, 2016).

CBH's centrepiece was the establishment in 1999 in Bangkok (formalised in 2001 in Kunming) of an inter-governmental disease-control mechanism involving the Ministry of Health of the six countries of the Greater Mekong Subregion (Cambodia, Laos, Myanmar, Thailand, Vietnam and China), named the Mekong Basin Disease Surveillance Consortium (MBDS). MBDS played a crucial trust-building role in joint efforts to contain consecutive outbreaks of the genetically related but diverse SARSCoV (severe acute respiratory syndrome coronavirus) in 2002 and H5N1 avian influenza in 2003 - both starting in China and spreading to the surrounding region and beyond before finally self-exhausting; and of later EIDs originating from other regions, such as the H1N1 swine flu pandemic in 2009 (Coker et al., 2011; Matysiak, 2014; Phommasack et al., 2013; Bond et al., 2017). Three specific phases of development can be identified in the first decade of MBDS development. In the first phase (20012003) focus was on building the national and local surveillance capacity in every member country, including through provision of opportunities for medical doctors from member countries to enrol in the Field Epidemiology Training Program in Thailand. In the second phase (2004-2007) activities centred on cross-border collaboration in 
eTropic 20.1 (2021) Special Issue: Pandemic, Plague, Pestilence and the Tropics

outbreak control, like the joint control of the H5N1 outbreak on the Laos-Thailand border in 2007. And in the third phase (2008-2011), greater attention was given to regular exchange of information among the neighbouring countries, particularly with regard to the then-emerging $\mathrm{H} 1 \mathrm{~N} 1$, and to greater participation in international partnerships and networks (Phommasack, n.d.; Bond et al., 2017).

Eventually, the Rockefeller Foundation was joined by the Nuclear Threat Initiative (NTI), which also benefited from support by the Google Foundation or Google.org, and later, the Skoll Global Threats Fund in supporting MBDS and related endeavours (The Nuclear Threat Initiative [NTI], 2008). Over time, these and other foundations consistently funded transdisciplinary collaborations to promptly detect, identify and respond to infectious diseases in the region, including the first-ever simulation exercise in 2007 to assess readiness for an eventual pandemic influenza emergency (NTI, n.d.). The US and European foundations' emphasis on collaborative knowledge and institutional capacity building was also shared by other grant-making organisations. In particular, the Canadian semi-governmental International Development Research Centre (IDRC) launched, in 2006, the Asian Partnership on Emerging Infectious Diseases Research (APEIR) involving leading government, non-government and academic institutes in selected countries in Southeast Asia and China to better understand and address the root causes of epidemics and to ensure pro-poor risk reduction and coping strategies (Silkavute et al., 2013).

The APEIR network promoted multi-disciplinary policy-relevant research on emerging infectious diseases from an EcoHealth perspective, which examines human well-being in relation to the interplay of ecological and socio-economic systems drawing from the humanities and the natural, social and health sciences (Harrison et al., 2019; Mallee, 2017). In its second programme phase, focus was on Southeast Asia's thriving and often illegal wildlife trade and its implications for disease transmission to humans, and other social and environmental impacts. The programme aimed to assess pathogens and possible transmission pathways from animals to humans (International Development Research Centre [IDRC], 2020). Collaborative research examined the multiple functions of wildlife regionally, including as a source of protein for the poor, and recommended public education and regulatory measures to reduce illegal wildife trade rather than abstract bans - a finding that counters the current frantic calls for the abolishment of wet markets, even those with no wild game (Lynteris \& Fearnley, 2020).

As more tech-related foundations became engaged, there was also interest in supporting technological design and application to serve disease surveillance and other health needs. In 2008, ILab was started in Cambodia by Innovative Support to Emergencies Diseases and Disasters (InSEDD) with assistance from Google.org to 
eTropic 20.1 (2021) Special Issue: Pandemic, Plague, Pestilence and the Tropics

build technological capacity for addressing health, safety, and developmental issues in the region - including working closely with the Cambodia Communicable Disease Control unit to strengthen its information and communication systems (InSEDD, n.d.). In later years, various technological innovations were developed and tested with philanthropic support, such as the PODD, the Participatory One Health Disease Detection smartphone app for use by volunteers to collect data and report potential outbreaks to local government officials adopted in Chiang Rai, Thailand, with assistance from the Skoll Global Threats Fund (opendream, n.d.).

Learning from these rich experiences in Southeast Asia, foundations also aimed to contribute to global preparedness. At a meeting held by the Rockefeller Foundation and NTI at the Rockefeller Foundation Bellagio Conference Center in Italy in 2007, experts and practitioners identified three "vital concerns" in public health surveillance of emerging infectious diseases in developing countries that deserved greater attention and investment:

(i) the need to build surveillance capacity, especially human and laboratory capacity, but also cross-border collaborative capacity; (ii) the need to develop and employ appropriate information and datasharing technology to facilitate timely communication during times of emergency; and (iii) the need for a flexible approach to governance among the growing number of regional infectious disease surveillance networks that are self-assembling worldwide (Gresham et al., 2013, p. 2).

In response to the growing appreciation of intra-regional collaboration by regional disease surveillance networks across the world, foundations promoted global exchange of practices and innovations. Most importantly, NTI, the Rockefeller Foundation, Peter G. Peterson Foundation, the Fondation Mérieux, and the Skoll Global Threats Fund jointly supported six networks - MBDS and APEIR included - to establish the Connecting Organizations for Regional Disease Surveillance (CORDS) in 2012. This organisation facilitated the interaction between networks covering human and animal diseases, as well as their further interaction with relevant international bodies, especially the World Health Organization (WHO), World Organization for Animal Health (IOE), and the Food and Agriculture Organization of the United Nations (FAO), as well as other key stakeholders, "to improve global surveillance and mitigate the potential impact of disease outbreaks both from epidemic diseases and from the recrudescence of endemic diseases" (Rodin et al., 2013, "Letter", para 3). 
eTropic 20.1 (2021) Special Issue: Pandemic, Plague, Pestilence and the Tropics

This pioneering philanthropic work was eventually reinforced by a flurry of bilateral and multilateral donor-supported initiatives in the region triggered by the occurrence of the SARS and H5N1 epidemics. The Asian Development Bank (ADB) with its first (20052009) and second (2010-2015) Greater Mekong Subregion Regional Communicable Diseases Projects allocated US\$ 38.75 million and US\$ 51 million respectively in grant and loan funds to the governments of Cambodia, Laos, Myanmar and Vietnam to strengthen health system capacity to address infectious diseases and support intraregional cooperation in health security (Asian Development Bank [ADB], 2016).

Significant resources were also invested by bilateral donors. AusAID (now dissolved into the Department of Trade and Foreign Affairs or DFAT) granted AUS\$ 194 million between 2006 and 2015 to strengthen human and animal health systems for the prevention and response to emerging infectious diseases in the Asia-Pacific region, focusing among other programmes, on: disease surveillance systems, health workforce epidemiological capacity, laboratories, and leadership and governance (Australian Government Department of Foreign Affairs and Trade [AGDFAT], n.d.).

USAID's Emerging Pandemic Threats (EPT) Program under the Lower Mekong Initiative (2011-2015) promoted early identification of dangerous pathogens in animals and routine disease detection in people (U.S. Department of State, 2012). With the emergence of the One Health concept as advocated by UN agencies around 2008, USAID also increasingly funded transdisciplinary interventions directed at the drivers of disease emergence. One Health brought together veterinary and human medicine to study human-animal disease transmission, and later broadened its scope to include varied agricultural and environmental challenges, with somewhat less emphasis on social sciences and humanities in comparison to EcoHealth (Harrison et al., 2019; Lemer \& Berg, 2017). It has also been noted that One Health "is evolving on a large scale and at official levels, whereas EcoHealth operates at a more grass-root, pragmatic level" (Roger et al., 2016, para 2). Under its One Health Workforce project, USAID funded the establishment of the Southeast Asia One Health University Network (SEAOHUN) in 2011 to develop the next generation of integrated One Health specialists and practitioners (Gongal, 2012), whose expansion across Southeast Asian countries also received Korean and other bilateral support.

A decade after SARS and H5N1, this concentration of resources and multidisciplinary approaches was recognised as being substantial (Coker et al., 2011) and as having contributed to better preparedness and progress in achieving the core capacities required to control emerging infectious diseases (Horby et al., 2013). National and community surveillance systems had been built or strengthened even in poor resource countries like Cambodia, Laos and Myanmar. Collaborations with scientists in China had delivered new knowledge on the origin of the viruses and their transmission. For 
eTropic 20.1 (2021) Special Issue: Pandemic, Plague, Pestilence and the Tropics

SARS-CoV, it is now thought that it originated in bats, and civet cats were the intermediary reservoir host; while bears, monkeys, and the endangered pangolin were also investigated (Zhao et al., 2020). Similar collaborative investigations are now being conducted for SARS-CoV-2, but this time amidst heightened mistrust and political tensions (Dwyer, 2021). The emergence of the concepts of EcoHealth and One Health was seen as significant progress towards a more comprehensive approach to zoonotic diseases crucial to obtaining success in disease control, surveillance and research. Innovative activities had been initiated to realise integrated human and animal surveillance systems with a generic, non-species and non-threat specific scope to be able to identify unexpected challenges. More awareness was also raised on the socioeconomic drivers and impacts of the epidemics. For instance, H5N1 discussions had been broadened to include exposure of unhealthy practices in the industrial poultry industry in China and Southeast Asia, and advocacy of compensation measures for farmers when the culling of backyard or free-range poultry was deemed necessary. Ethical and human rights issues were also highlighted in relation to intrusive epidemiological measures. Overall, there was optimism that countries could work together to fill the missing gaps and succeed in operationalising the now-formulated regional and national surveillance plans into concrete actions at the local level.

\section{Decline of Donor Interest}

Gradually, however, funding initiatives declined in value, scope and intensity due to both internal as well as external factors. Factors internal to grant-making institutions and more generally the philanthropic sector included a leadership transition at the Rockefeller Foundation, which led to the closure of LAB and CBH in 2007. So-called 'legacy grants' were given to complete ongoing efforts and a final five-year investment of US\$ 22 million for the now-renamed Disease Surveillance Networks (DSN) initiative was made. When the funding ended in 2012 an evaluation hastily concluded that the set goals had been achieved (The Rockefeller Foundation, n.d.). Likewise, at IDRC internal decisions caused the closing of the regional office for East and Southeast Asia in Singapore in 2013 with support for APEIR continuing at reduced capacity thereafter. More importantly, the emergence since 2000 of a more universalist, technocratic, and market-oriented paradigm in philanthropy - sparked by the establishment of BMGF, but grounded in changed political and economic changes across the globe - dismissed contextual, bottom-up and human rights-based approaches, narrowed health to technical processes, reduced partnerships with civil society, invested less in institutional capacity building and discouraged 'field office presence' in a 'flat world' consonant with uniform global initiatives (see Sciortino, 2016; 2017). A number of foundations left the area and those who stayed embraced a more technocratic agenda less responsive to socio-cultural and institutional contexts and with less direct funding 
eTropic 20.1 (2021) Special Issue: Pandemic, Plague, Pestilence and the Tropics

to local organisations and especially civil society groups. ${ }^{5}$ Engagement with China was also reduced owing to polarised views, more restrictive rules for overseas foundations in China and awe for the growing number of Chinese foundations (irrespective of their different priorities).

Among the external trends were donors' reductions of international aid, and, above all, a retrenchment from the social sector in favour of macro-economic and infrastructure investments. Some data suggest that, with the exception of an increase in funding to address Ebola, aid for the health sector stayed flat during the period 2010-2016 and declined thereafter (Bendavid et al., 2017; World Health Organization [WHO], 2019). This decline was clearly felt in Southeast Asia, which as a whole, scored low on foreign assistance prioritisation, and was regarded as ready to 'graduate' from aid - despite growing inequities, persistent vulnerabilities, weak health and social protection systems, worsening environmental degradation, and unresolved development challenges.

This less-resourced global health agenda generally focused on the 'established causes' of: mother and child health $(\mathrm{MCH})$, reproductive health, and the three priority communicable diseases of HIV, malaria and tuberculosis. The agenda also began to increasingly emphasise non-communicable diseases (NCDs) - including cancer, cardiovascular diseases, and diabetes - as the leading causes of global death and disease worldwide, rather than infectious diseases. Concerns regarding NCDs being a major contributor to public expenditures and households' out-of-pocket spending eventually compelled the international donor community to focus on Universal Health Coverage (UHC). Much needed investments in health financing schemes, however, too often came at the cost of former programmes that had aimed at strengthening primary health services. The narrow definition of UHC as "a means of protection against the economic consequences of ill health" overshadowed the broader goal of achieving a universal right to health for entire populations and especially for the marginalised, which would require reaching beyond mere health service provision to emphasise preventive and promotive approaches and include deliberate efforts to address the determinants of health such as education, gender and sanitation (Abiiro \& De Allegri, 2015). The privatisation and marketisation of health care - pursued by governments and donors alike - weakened interest in the funding of programmes to improve public health provision. Moreover, emphasis on short-term global interests acted to compromise the resourcing of long-term capacity building initiatives within national and community health systems.

\footnotetext{
${ }^{5}$ For an extensive analysis of these changes see Sciortino $2016,2017 \& 2018$.
} 
eTropic 20.1 (2021) Special Issue: Pandemic, Plague, Pestilence and the Tropics

With regards to infectious diseases, funding in the region was more narrowly targeted at malaria and to a lesser extent dengue fever and tuberculosis. In 2013 the BMGF in partnership with the $\mathrm{WHO}$ and bilateral donors launched an ambitious campaign to eliminate malaria from the Greater Mekong Subregion in order to prevent the emergence of drug and insecticide-resistant strains. This approach to achieve zero transmission came to dominate the donor agenda. In the same year, ADB established the Regional Malaria and Other Communicable Disease Threats Trust Fund (RMTF) with US\$ 29 million in funds from Australia, the UK and Canada, which was later expanded with an additional US\$ 125 million worth of loans and grants for health security in the Greater Mekong Subregion countries and redirected from supporting malaria control to the more ambitious goal of totally eliminating this public health threat (Roth \& Parry, 2018).

Meanwhile, attention regarding new and re-emerging diseases shifted to the US with the 2009-2010 H1N1 influenza (swine flu) pandemic; then to the Middle East during the MERS epidemic caused by another coronavirus in 2012; to the Americas for the duration of the Zika epidemic in 2015-2016; and across to Africa for the largest Ebola outbreak in 2014-2016 in West Africa, and again in 2018-2019 for another outbreak in the Democratic Republic of Congo. The fear of fast-spreading highly pathogenic epidemics from Asia had lessened as the impact of SARS and H5N1 avian influenza had been mainly limited within the region; and there was confidence that the spread of eventual recurring outbreaks could be contained (The National Health Service UK, 2017). As an indication of this sense of the changing perception of risk, funding from the United States' National Institute of Allergy and Infectious Diseases under the National Institutes of Health for coronavirus research was US \$104.7 million in 2004, dropped to US\$14.9 million by 2010, increased after MERS in 2012, to eventually reach US\$27.7 million in 2019 - still radically below the 2004 funding level. Resources were mainly allocated to influenza since it was rationalised that: "SARS hadn't come back, and other coronaviruses known to infect humans caused only common colds" (McKay \& Dvorak, 2020, para 1).

On the $10^{\text {th }}$ anniversary of SARS in 2013, a study assessing the prospects for EIDs prevention and control in East and Southeast Asia concluded that despite significant improvements and better preparedness, rapid changes in the region and the real possibility that new pathogens would emerge, indicated the continued need to ensure that "the capacity to predict and identify biologic threats and to protect the public's health does not stagnate as the memory of SARS fades" (Horby et al., 2013, last para). Similarly, a WHO expert meeting in February 2018 expressed fear of an inevitable 'Disease X", most probably of zoonotic origin, emerging from a number of hot spots, including southern China, and of greater epidemic proportions. Among the possible viruses that could emerge, as the president of the EcoHealth Alliance, Daszack, stated 
eTropic 20.1 (2021) Special Issue: Pandemic, Plague, Pestilence and the Tropics

at the meeting, were the hundreds identified coronaviruses which posed "a clear and present danger" (McKay \& Dvorak, 2020, para 14).

These and other repeated expert warnings, were, however, largely ignored by the same philanthropic foundations and like-minded organisations that had spearheaded infectious disease surveillance at the very dawn of SARS. The warnings were likewise not heeded by donor agencies and national governments. With no perceived threat of an immediate outbreak, systemic pandemic preparedness became underfunded.

\section{Learning from Past Efforts and their Dismissal}

COVID-19 thus emerges in the midst of an unfinished agenda and makes the promising investments of the early 2000s look like a missed opportunity. Despite the popularity of conspiracy theories, they can be easily dismissed because, as the decades-long work presented above testifies, the emergence of a new strain of coronavirus linked to wild game in China is not surprising - and could and should have been expected. It is therefore important to look back in order to draw lessons from these previous efforts and analyse the factors that contributed to their dismissal.

The COVID-19 crisis alerts us to the fact that it is imperative that health - understood as socially determined and not just as a bio-medical issue - and health care, gain greater relevance in international funding (and government agendas). While donor funding, and especially funding by philanthropic foundations, forms a minimal part of global spending on health, they nevertheless remain an important supplement to local government and commercial resources in low and lower-middle income countries such as the majority of those of Southeast Asia. The pandemic likewise signals the need for greater public discussion regarding the prioritisation of funding. For instance, there could be a closer examination of the efficiency of concentrating resources in a vertical approach for 'fighting' specific diseases, foremost malaria, as has been the emphasis of recent foundation endeavours, especially by BMGF and its multi-lateral partners. A comparison could be made with a broad-based horizontal approach that builds system capacity to deal with a wider range of health problems and their underlying causes, as was the case with the early programmes focusing on strengthening disease surveillance capacity and supporting health system reforms for the public good.

Funding allocation should further revalue the acknowledgment by philanthropic foundations and like-minded organisations at the turn of the millennium, that health is intrinsically related to socio-cultural and political processes, shaped by specific contexts. COVID-19 is revealing that although the preventive measures at our disposal are meant for the entire global community, no homogeneous approach could be taken, since: 
eTropic 20.1 (2021) Special Issue: Pandemic, Plague, Pestilence and the Tropics

there is no universal guideline on their right mix and no consensus on the degree of enforcement required to ensure people's adherence. Achieving a successful mix of interventions both in the midst of the COVID-19 pandemic and for exit strategies is contextually defined (Sciortino \& Saini, 2020, Section 2, para 2).

In view of this heterogeneity it is crucial to give more direct support to home-grown initiatives and organisations since they are best placed to work within local complexities. As we are seeing in this pandemic, the response to COVID-19 has been very much localised and it is the institutions on the ground (governments and non) that are acting. Foundations (and other donors) should re-emphasise direct grant-making to local organisations, rather than favouring international organisations, UN agencies and corporate contractors as their intermediaries. Grant-making strategies should be defined from the ground-up as was the case with the $L A B$ and its $C B H$ component, which were formulated after extensive consultation with local stakeholders. Furthermore, calls for proposals should not be prescriptive in order to allow local organisations to 'own' solutions rather than being reduced to 'implementers' of topdown defined strategies. A range of smaller and larger grants could be offered to include different types of organisations with varying levels of absorption capacity (see also Sciortino, 2016; 2017; 2018).

Foundations' insights from past experience have shown that medical interventions cannot be disjointed from issues of equity, people's rights, socio-economic justice and accountable governance of systems. These lessons appear to be particularly relevant today as COVID-19 highlights the profound inequities affecting marginalised groups and the tensions between individual freedoms and health security - as a July UN Secretary General's Policy Brief on the impact of COVID-19 on Southeast Asia comprehensively documents (UN, 2020). Many governments in this region are failing to take into account the rights and needs of the most socially vulnerable groups, especially informal workers and migrants. There is an urgency to advocate for more inclusive social protection and the provision of basic support:

The pledge to provide a safety net or any form of social security also poses another problem; whether it will cover migrant workers, informal, casual, domestic, and temporary workers equally. Although international law stipulates an obligation for states to eliminate any barrier for these workers to access the most basic form of social security, domestic laws and regulations in several $A S E A N^{6}$ member

\footnotetext{
${ }^{6}$ The Association of South East Asian Nations (ASEAN) is the regional body of countries in Southeast Asia, with the exception of Timor Leste.
} 
eTropic 20.1 (2021) Special Issue: Pandemic, Plague, Pestilence and the Tropics

states still exclude these people from fully practicing their rights (Virgil, 2020, para 5).

Supporting civil society groups and the representation of different sectors to express their specific views and needs is also essential in ensuring more balanced and rightsbased decisions at a time when quarantine, isolation of patients and their families, technological tracking devices, and other intrusive measures, are being employed at an unprecedented scale. If we want to secure community voices at all levels, side-byside governments and the corporate sector, a rethinking of development aid and a $U$ turn in philanthropy are required in order to stop the financial and political undermining of civil society that has been occurring over recent years (Sciortino, 2018).

The example set by past programmes also reminds us that geographical and disciplinary boundaries need to be transcended and that investments are required in order to continue to (re)build and maintain the capacity to do so. COVID-19 has demonstrated that the trust fostered by previous programmes has waned and countries have failed to coordinate with each other. After a period of limited activities, MBDS, now an official regional foundation, is reinstating some cross-border programmes in relation to the pandemic, but COVID-19 tracking is outside its realm with its website showing regional data as reported by international platforms (MBDS, 2021). Regional sharing of information has remained minimal and national lockdowns have been imposed without bilateral or regional consultations (Vatiokis, 2020; Pham, 2020). For instance, in Thailand, the hastily announced border closure order in March 2020 triggered a mass exodus of migrants from Myanmar, Cambodia and Laos without time for preparation in their countries of origin (International Organization for Migration [IOM], 2020). Long-term strategies will be needed to rebuild the institutional trust for cross-border collaboration and tackle the geo-political, economic and cultural barriers that have halted it.

Similarly, the rationale for the interdisciplinary One Health or Ecohealth approach - or a combination of the two, possibly also in interaction with the more recent concept of Planetary Health (Lerner \& Berg, 2017) - is clearly warranted, as we have been reminded recently by WHO statements that wildife farms in Southern China may be a likely source of the pandemic and "the perfect conduit between a coronavirus-infected bat in Yunnan (or neighbouring Myanmar) and a Wuhan animal market" (Doucleff, $2021,2^{\text {nd }}$ last para). Yet, if such an interdisciplinary approach is to function, greater efforts need to be made by governments and their international partners to support its institutionalisation at different levels and contextualisation in varied settings. Most importantly, radical steps are implied to reform economic and environmental systems. 
eTropic 20.1 (2021) Special Issue: Pandemic, Plague, Pestilence and the Tropics

Integrated research and action furthermore requires changes in the sectoral allocation of resources. While the Southeast Asian public is looking forward to the result of BMGF and others' investments for better coronavirus treatments and a COVID-19 vaccine, early philanthropic efforts such as those discussed in the previous sections remind us that technical, one-dimensional, solutions are not sufficient. Funding for social interventions is equally important in order to prevent and contain present and future epidemics and address their root causes, the inequities causing differential vulnerabilities, and the wide range of socio-economic impacts.

For philanthropic foundations and semi-public grant-making organisations like IDRC, their value may not necessarily be in the volume of funding. As stated before, in spite of public perception, the funds such foundations grant - with the possible exception of BMGF - are smaller than government resources and bilateral and multi-lateral donor funding. Rather, their strength, as was shown in the previous section, is their capacity at being responsive to local needs, directly supporting local initiatives and organisations to address these needs, and investing in critical issues and innovative approaches. They can offer visionary leadership in health as they can afford to take more risks than other donors, choose 'the road less travelled' to explore programmatic approaches, and use their convening power to get other stakeholders on board to maximize impact. However, as the above recount of foundations' engagement with emerging infectious diseases in Southeast Asia has shown, these qualities cannot be taken for granted. While foundations were at the avant-garde of emerging disease surveillance in the region in the early 2000s they gradually came to lose both their vision and their leadership. Deeper critical discussions regarding the performance of philanthropy and philanthropic foundations in addressing crucial development and health issues need to be held, including on the impacts of the aforementioned shift towards a more globalised, technocratic and business-oriented model of philanthropy. This discussion should be based on actual practices, rather than sweeping normative statements, as much of the public appraisal and criticism of philanthropy, briefly described in the introductory section, often tends to be.

The rupture caused by the COVID-19 pandemic may thus become an opportunity to examine philanthropic foundations' current modus operandi in Southeast Asia to assess whether they are still uniquely positioned to provide strategic, bold and sociallyresponsive funding, as they used to be at the beginning of the 2000s. If this is not the case, as observations and literature suggest, there is a growing urgency to investigate the transformative practices that can be revived or newly invented for the control of emerging infectious diseases and interconnected health, social and environmental issues. Paraphrasing Arundhati Roy's (2020) words, COVID-19 may be the portal to a new future, but reflection and change will be needed if philanthropy is to play a meaningful role in creating an eco-sustainable, healthier and more just world. 
eTropic 20.1 (2021) Special Issue: Pandemic, Plague, Pestilence and the Tropics

\section{References}

Abiiro, G. A., \& De Allegri, M. (2015). Universal health coverage from multiple perspectives: A synthesis of conceptual literature and global debates. BMC International Health and Human Rights, 15(1), 17. https://doi.org/10.1186/s12914-015-0056-9

Asian Development Bank [ADB]. (2016). Project Administration Manual-Greater Mekong Subregion Health Security Project. https://www.adb.org/sites/default/files/projectdocument/212781/48118-002-pam.pdf

Australian Government Department of Foreign Affairs and Trade [AGDFAT]. (n.d.).

Pandemics and emerging infectious diseases.

https://www.dfat.gov.au/development/performance-assessment/aidevaluation/strategic-evaluations/pandemics-and-emerging-infectious-diseases

Bendavid, E., Ottersen, T., Peilong, L., Nugent, R., Padian, N., Rottingen, J.-A., \& Schäferhoff, M. (2017). Development Assistance for Health. In D. T. Jamison, H. Gelband, S. Horton, P. Jha, R. Laxminarayan, C. N. Mock, \& R. Nugent (Eds.), Disease Control Priorities: Improving Health and Reducing Poverty (3rd ed.). The International Bank for Reconstruction and Development / The World Bank. http://www.ncbi.nlm.nih.gov/books/NBK525305/

Bill \& Melinda Gates Foundation [BMGF]. (2020). COVID-19—Bill \& Melinda Gates Foundation. https://ww2.gatesfoundation.org/ldeas/Campaigns/COVID\%2019

Bond, K., MacFarlane, S., Burke, C. Ungchusak, K. \& Wilbulpolprasert, S. (2017) The Evolution and Expansion of Regional Disease Surveillance Networks and Their Role in Mitigating the Threat of Infectious Disease Outbreaks Emerging Health Threats Journal 6(1). https://doi.org/10.3402/ehtj.v6i0.19913

Coker, R. J., Hunter, B. M., Rudge, J. W., Liverani, M. \& Hanvoravongchai, P. (2011) Emerging Infectious Diseases in Southeast Asia: Regional Challenges to Control. The Lancet 377, Issue 9765: 599-609. https://doi.org/10.1016/S01406736(10)62004-1

Doucleff, M. (2021, March 15). WHO Points To Wildlife Farms In Southern China as Likely Source of Pandemic. NPR.

https://www.npr.org/sections/goatsandsoda/2021/03/15/977527808/who-points-towildlife-farms-in-southwest-china-as-likely-source-of-pandemic

Dwyer, D. (2021, February 22). I was the Australian doctor on the WHO's COVID-19 mission to China. Here's what we found about the origins of the coronavirus. The Conversation https://theconversation.com/i-was-the-australian-doctor-on-the-whoscovid-19-mission-to-china-heres-what-we-found-about-the-origins-of-the-coronavirus155554

European Foundation Center [EFC]. (2020, July 23). How are EFC members mitigating the impact of COVID-19? https://www.efc.be/news-post/how-are-efc-members-mitigatingthe-impact-of-covid-19/

Fauci, A. S., Touchette, N.A. \& Folkers, G.K. (2005) Emerging Infectious Diseases: a 10Year Perspective from the National Institute of Allergy and Infectious Diseases. Emerging Infectious Diseases 11(4), 519-525. https://dx.doi.org/10.3201/eid1104.041167

Gaspard, P. (2020, April 16). Going Big against COVID-19. Open Society Foundations. https://www.opensocietyfoundations.org/voices/our-emergency-response-to-covid-19

Gongal, G. (2012). One Health Approach in the South East Asia Region: Opportunities and Challenges. One Health: The Human-Animal-Environment Interfaces in Emerging Infectious Diseases, 366, 113-122. https://doi.org/10.1007/82 2012242

Gresham, L. S., S. Smolinski, M., Suphanchaimat, R., Marie Kimball, A., \& Wibulpolprasert, S. (2013). Creating a Global Dialogue on Infectious Disease Surveillance: 
eTropic 20.1 (2021) Special Issue: Pandemic, Plague, Pestilence and the Tropics

Connecting Organizations for Regional Disease Surveillance (CORDS). Emerging

Health Threats Journal, 6(1), 19912. https://doi.org/10.3402/ehtj.v6i0.19912

Hamilton, I. A. (2020, April 16). How much of their wealth tech billionaires donate to fight coronavirus-Business Insider. Business Insider.

https://www.businessinsider.com/silicon-valley-tech-billionaires-wealth-proportioncoronavirus-relief-2020-

4?utm source=Iterable\&utm medium=email\&utm campaign=campaign $1142779 \& \mathrm{ci}$ $\mathrm{d}=$ pt\&source=ams\&sourceld=223704\#jeff-bezos-2

Harrison, S., Kivuti-Bitok, L., Macmillan, A., \& Priest, P. (2019). EcoHealth and One Health: A theory-focused review in response to calls for convergence. Environment International, 132, 105058. https://doi.org/10.1016/j.envint.2019.105058

He, L. (2020, April 29). COVID-19 and Chinese Philanthropy Abroad: Part 1. Medium. https://medium.com/@chinaphilanthropy/covid-19-and-chinese-philanthropy-abroadpart-1-4b8582d5c9a7

Hobson, W. (2020, May 1). Covid-19 relief effort by Soros's foundation is criticized by its own employees. Washington Post. https://www.washingtonpost.com/lifestyle/covid-19relief-effort-by-soross-foundation-is-criticized-by-its-ownemployees/2020/05/01/e7f5d79c-8aeb-11ea-ac8a-fe9b8088e101 story.html

Horby, P. W., Pfeiffer, D., \& Oshitani, H. (2013). Prospects for Emerging Infections in East and Southeast Asia 10 Years after Severe Acute Respiratory Syndrome. 19(6), 853860. https://doi.org/10.3201/eid1906.121783

Innovative Support to Emergencies Diseases and Disasters [InSEDD]. (n.d.). FAQ. https://instedd.org/about-us/faq/

Intelligencer. (2020, April 10). Kara Swisher, Scott Galloway on Tech Giving: 'It's Lipstick, Not Philanthropy.' https://nymag.com/intelligencer/2020/04/kara-swisher-scottgalloway-jack-dorsey-billion-dollar-gift.html

International Development Research Centre [IDRC]. (2020, August 27). Linking Emerging Infectious Diseases Research and Policy Networks in Southeast Asia and China:

APEIR Phase II. https://www.idrc.ca/en/project/linking-emerging-infectious-diseasesresearch-and-policy-networks-southeast-asia-and-china

International Organization for Migration [IOM]. (2020, 26 March) COVID-19 response. Flash Update: Migration movement in the Greater Mekong Sub-region.

https://thailand.iom.int/sites/default/files/COVID19Response/DTM COVID Update/C OVID\%20Response\%20SitRep GMS\%20Flash\%20Update.pdf

Jung, T. \& Harrow, J. (2016) Philanthropy, the State and Public Good. In P. Guerrero O, P. Wilkins (Eds.) Doing Public Good?: Private Actors, Evaluation and Public Value (pp. 29-46). Transaction Publishers.

Lerner, H., \& Berg, C. (2017). A Comparison of Three Holistic Approaches to Health: One Health, EcoHealth, and Planetary Health. Frontiers in veterinary science, 4, 163. https://doi.org/10.3389/fvets.2017.00163

Lim, J. (2020, April 19). Coronavirus: Are Singapore's tycoons extending a helping hand? The Straits Times. https://www.straitstimes.com/singapore/health/are-spore-tycoonsextending-a-helping-hand

Lynteris, C., \& Fearnley, L. (2020, January 31). Why shutting down Chinese 'wet markets' could be a terrible mistake. The Conversation. http://theconversation.com/whyshutting-down-chinese-wet-markets-could-be-a-terrible-mistake-130625

M2030. (2020, April 6). Mayapada Group and Tahir Foundation lead response to COVID-19. https://m2030.org/2020/04/06/mayapada-group-and-tahir-foundation-lead-responseto-covid-19/

Mallee, $\mathrm{H}$. (2017). The evolution of health as an ecological concept. Current Opinion in Environmental Sustainability, 25, 28-32. https://doi.org/10.1016/j.cosust.2017.04.009

Matysiak, A. (2014). Health and Well-Being. The Rockefeller Foundation. 
eTropic 20.1 (2021) Special Issue: Pandemic, Plague, Pestilence and the Tropics

McKay, B. \& Dvorak, P. (2020, 13 August) A Deadly Coronavirus Was Inevitable. Why Was No One Ready? The Wall Street Journal https://store.wsj.com/shop/apac/wsjssas21/?trackingCode=aaqwghul\&cid=WSJ RD ALL ACQ NA

Neate, R. (2020, April 11). Call for super-rich to donate more to tackle coronavirus pandemic. The Guardian. http://www.theguardian.com/news/2020/apr/11/call-forsuper-rich-to-donate-more-to-tackle-coronavirus-pandemic

Opendream. (n.d.). OPDD. https://www.opendream.co.th/en/project/podd-en

Pham, P. (2020, 7 July). "COVID-19 Has Revealed ASEAN's Institutional Weaknesses". Lee Kuan Yew School of Public Policy. https://lkyspp.nus.edu.sg/gia/video/covid-19has-revealed-asean-s-institutional-weaknesses

Philanthropy News Digest. (2020, January 31). Jack Ma Commits $\$ 14.4$ Million for Coronavirus Vaccine Efforts. https://philanthropynewsdigest.org/news/jack-macommits-14.4-million-for-coronavirus-vaccine-efforts

Phommasack, B. (n.d.). Rationale \& History of the Establishment of MBDS. MBDS Net. http://www.mbdsnet.org/wp-content/uploads/2013/07/MBDS-Evolution Dr.Bounlay .pdf

Phommasack, B., Jiraphongsa, C., Oo, M. K., Bond, K. C., Phaholyothin, N., Suphanchaimat, R., Ungchusak, K., \& Macfarlane, S. B. (2013). Mekong Basin Disease Surveillance (MBDS): A Trust-Based Network. Emerging Health Threats Journal, 6(1), 19944. https://doi.org/10.3402/ehtj.v6i0.19944

Rodin, J., Nunn, S., Miribel, B., \& Brilliant, L. (2013). Letter Emeging Health Threats. 6. http://dx.doi.org/10.3402/ehtj.v6i0.19912

Roger, F., Caron, A., Morand, S., Pedrono, M., de Garine-Wichatitsky, M., Chevalier, V., Tran, A., Gaidet, N., Figuié, M., de Visscher, M. N., \& Binot, A. (2016). One Health and EcoHealth: the same wine in different bottles? Infection Ecology \& Epidemiology, 6, 30978. https://doi.org/10.3402/iee.v6.30978

Roth, S., \& Parry, J. (2018). Regional Malaria and Other Communicable Disease Threats Trust Fund: Final Report (0 ed.). Asian Development Bank. https://doi.org/10.22617/TCS189605-2

Roy, A. (2020, April 4). The pandemic is a portal. Financial Times. https://www.ft.com/content/10d8f5e8-74eb-11ea-95fe-fcd274e920ca

Sall, E. (2020). COVID-19 Africa Solidarity Fund. Turst Africa. https://bos.etapestry.com/prod/viewEmailAsPage.do?erRef=1538.0.2058703\&databa seld=TrustAfrica\&mailingld=39323100\&jobRef $=1538.0 .12151942 \& \mathrm{key}=68 \mathrm{a} 83 \mathrm{eeb} 49$ 4a308fe5295da69428a57

Schleifer, T. (2020, April 7). The risks of relying on Bill Gates and Jack Dorsey in the coronavirus crisis. Vox. https://www.vox.com/recode/2020/4/7/21203179/coronavirusbillionaires-philanthropy-bill-gates-larry-ellison-mark-zuckerberg-jack-dorsey

Sciortino, R. (2016). "Learning Across Boundaries": Grantmaking Activism in the Greater Mekong Subregion. In Salemink, O. (Ed.) Scholarship and Engagement in Mainland Southeast Asia (1st ed.), Chapter 6, pp. 141-166). Chiang Mai: Silkworm Press. https://www.researchgate.net/publication/287260464 Learning Across Boundaries Grantmaking Activism in the Greater Mekong Subregion

Sciortino, R. (2017). Philanthropy, Giving, and Development in Southeast Asia. Austrian Journal of South-East Asian Studies, 10(2), 129-138. https://doi.org/10.14764/10.ASEAS-2017.2-1

Sciortino, R. (2018, July 11). Wielding the purse strings of Southeast Asian civil society. New Mandala. https://www.newmandala.org/weilding-purse-strings/

Silkavute, P., Tung, D. X., \& Jongudomsuk, P. (2013). Sustaining a Regional Emerging Infectious Disease Research Network: A Trust-Based Approach. Emerging Health Threats Journal, 6(1), 19957. https://doi.org/10.3402/ehtj.v6i0.19957 
eTropic 20.1 (2021) Special Issue: Pandemic, Plague, Pestilence and the Tropics

The National Health Service UK. (2017, October 19). SARS (severe acute respiratory syndrome). Nhs.Uk. https://www.nhs.uk/conditions/sars/

The Nuclear Threat Initiative [NTI]. (n.d.). Mekong Basin Disease Surveillance Network. https://www.nti.org/about/projects/mekong-basin-disease-surveillance-network/

The Nuclear Threat Initiative [NTI]. (2008, January 17). NTI's Global Health and Security Program Receives Major Grant from Google Foundation. https://www.nti.org/newsroom/news/nti-receives-grant-google-foundation/

The Rockefeller Foundation. (n.d.). Disease Surveillance Networks Initiative. https://www.rockefellerfoundation.org/report/disease-surveillance-networks-initiative/

U.S. Department of State. (2012, July 13). Lower Mekong Initiative. //20092017.state.gov/r/pa/prs/ps/2012/07/194963.htm

United Nations [UN]. (2020, July. Policy brief: The impact of COVID-19 on South-East Asia. New York: UN https://www.un.org/sites/un2.un.org/files/sg policy brief covid southeast asia 30 july 2020.pdf

Vatikiotis, M. (2020, 11 November). COVID-19 exposes ASEAN's fragility. NikkeiAsia https://asia.nikkei.com/Opinion/COVID-19-exposes-ASEAN-s-fragility

Virgil, D. (2020, 16 April) Covid-19 response: What's next? Bangkok Post https://www.bangkokpost.com/opinion/opinion/1900885/covid-19-response-whatsnext-

Wakefield. (2020, June 5). How Bill Gates became the voodoo doll of Covid conspiracies. BBC News. https://www.bbc.com/news/technology-52833706

World Health Organization [WHO]. (2019). Global Spending on Health: A World in Transition. https://www.who.int/health financing/documents/health-expenditurereport-2019.pdf?ua $=1$

Zhao J., Cui, W. \& Tian, B. (2020) The Potential Intermediate Hosts for SARS-CoV-2. Front. Microbiol. 11, 580137. https://doi.org/10.3389/fmicb.2020.580137

\section{Acknowledgements}

I would like to thank Fabio Saini and Giuseppe Sciortino for their editing of a shorter version of this article, the anonymous reviewers for their constructive comments, and Anita Lundberg for the comprehensive final editing.

Dr Rosalia Sciortino Sumaryono is Associate Professor at the Institute for Population and Social Research, Mahidol University, Visiting Professor at the Master in International Development Studies (MAIDS), Chulalongkorn University, and Director SEA Junction (seajunction.org). Most recently, she was IDRC Regional Director for Southeast and East Asia (2010-2014), Senior Adviser to AusAID in Indonesia (20092010), and Regional Director for Southeast Asia of the Rockefeller Foundation (20002007). She also served as program officer at the Indonesia and Philippines offices of the Ford Foundation (1993-2000). She received her doctoral degree cum laude from the Vrije Universiteit in Amsterdam and has published widely on development issues in Southeast Asia. In November 2017, she received a medal by the Vietnamese Association of Social Sciences for her contribution to social sciences in Vietnam. 